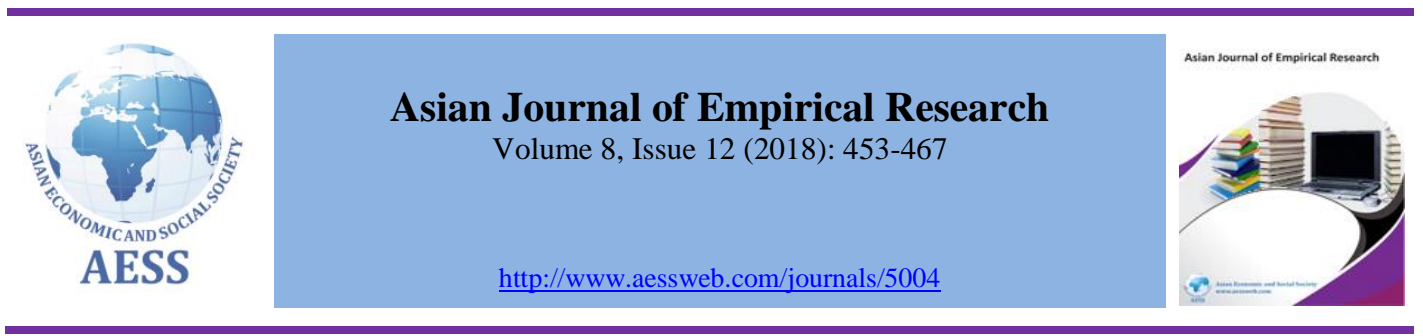

\title{
Developing the corporate global leadership bench strength through transformational leaders
}

\section{Prabhashini Wijewantha}

Senior Lecturer; Department of Human Resource Management, Faculty of Commerce and Management Studies, University of Kelaniya, Sri Lanka.

\section{prabhashini@kln.ac.lk /prabha2274@gmail.com (Corresponding author)}

\section{ARTICLE HISTORY:}

Received: $15-\mathrm{Nov}-2018$

Accepted: 11-Jan-2019

Online available: 18 -Feb-2019

\section{Keywords:}

Global leadership,

High-potential employees, Leadership bench strength development,

Multi-national corporations (MNCs),

Talent management, Transformational leadership

\begin{abstract}
Developing the global leadership bench strength by advancing the global leadership competencies of high potential employees is a critical concern for Multinational Corporations (MNCs), to achieve sustainable competitive advantage. Accordingly, the main purpose of this paper is to emphasize the role of line managers transformational leadership in developing the global leadership competencies of their respective subordinates, with the theoretical support of the transformational leadership theory. For the above purpose, data were collected from line manager-high potential dyads, using a structured questionnaire developed using well accepted, standard measures. Upon completion of preliminary analyses, the hypothesis was tested. From the regression analyses, it was found that there is a major impact of line manager's transformational leadership in the development of global leadership competencies of high potential subordinates. This finding is consistent with the transformational leadership theory and other empirical studies in the area and suggests the development of line manager's transformational leadership competencies for the purpose of developing the global leadership bench strength in MNCs.
\end{abstract}

\section{Contribution/ Originality}

Though leadership studies are common, there is a huge dearth of studies focusing on developing the leadership bench strength, and this study caters to that requirement. Furthermore, it is very much important to look at strengthening the leadership bench strength in MNC subsidiaries operating in emerging markets with the expansion of western MNCs to emerging markets in Asia, where the MNCs often find difficult to grab the best talent.

DOI: $10.18488 /$ journal.1007/2018.8.12/1007.12.453.467

ISSN (P): 2306-983X, ISSN (E): 2224-4425

CrossMark

How to cite: Prabhashini Wijewantha (2018). Developing the corporate global leadership bench strength through transformational leaders. Asian Journal of Empirical Research, 8(12), 453-467.

(C) 2018 Asian Economic and Social Society. All rights reserved 


\section{INTRODUCTION}

Superior talent is a prime source of sustainable competitive advantage for organizations (Rabbi et al., 2015) and hence, managing talent is a top-of-mind issue of business leaders world over. One vital trend in managing talent is identifying promising leaders among the talent pool of the organization and developing them to take over leadership positions in the future. Developing and retaining effective leaders is not only a talent management priority but also an overall business necessity, given the current business context. As identified by Beamond et al. (2016), leadership development is, mainly cultivating key leadership competencies among middle managerial level high potentials after identifying their leadership potential and recognizing them as suitable successors to current leaders by placing them in right development paths. Considering the growing importance of leadership development, and the increasing need of the corporate world to have competent leaders, this study is directed at a major aspect within talent management and leadership development domains- developing future leaders for organizations.

In the global business context, the leaders should be global leaders with global leadership competencies, irrespective of the extent that their business regime expands (Osland, 2017). Beamond et al. (2016) state that, emphasis on global leadership is a critical success factor for large Multinational Corporations (MNCs). However, due to the significance of leadership in the MNC setup, it is observed that MNCs not only focus on developing their current leaders into global leaders but also have gone one step further, to focus on developing the next generation of leaders. According to Gurdjian et al (2014), most organizations today, have failed to cultivate leadership talent within their junior managers and consequently, face a leadership succession crisis. However, the desired expectation of MNCs is to have a sufficient supply of leaders with expected global leadership competencies to take over leadership once the current leaders either move up or outside.

In a preliminary study undertaken by the author among HR Managers in MNCs in Sri Lanka, it was found that there is a major concern over the failure of many high potentials as leaders, even though they are being groomed to be successors of key positions. According to the interviewees, only a few high potentials demonstrate global leadership competencies once they take up leadership positions, despite having other technical capabilities. This observation is common across all global corporations around the world. A statement by a respondent to a survey of the Association for Human Resources Management in International Organizations (2010) confirms this, - "our high potentials may be very good in their subject, but they are not good leaders!" (p. 18). Furthermore, the managers in our preliminary survey further revealed that the reason for this leadership problem is not shortcomings with inherent leadership skills of these high potentials as all of them are rigorously evaluated for leadership skills at the selection process. Most web resources and scholarly publications available on high potentials focus only on 'identifying' high potentials (Al Ariss et al., 2014; Sparrow et al., 2015), but only a limited number of papers have addressed the issue of their failure in leadership positions. Most studies that have observed this problem propose the solution of providing leadership training for the high potentials and not any other alternatives. But in the observed local context, the issue remains regardless of the efforts by the HR Departments of MNCs to provide high potentials with training opportunities related to leadership.

Mendenhall et al. (2017) have found that most of the present research on developing global leadership competencies of high potentials are limited to descriptive essays written using small-scale samples, to share consulting experiences of authors with a focus on few countries. Therefore, they emphasize the need to undertake more research on every aspect of global leadership development. In earlier generations, global leadership competencies were not needed (Bird and Mendenhall, 2016), and it could be a reason for this dearth of literature in the area. 
In addressing this issue, this paper attempts to investigate the impact of transformational leaders, considering their ability to develop the leadership competencies of their subordinates, based on the transformational leadership theory (Burns, 1978; Bass, 1985). The main proposition of the theory is that transformational leaders contribute to follower leadership development. Accordingly, the following research question is addressed in this study.

\section{Is there an association between line managers' transformational leadership and global leadership competencies of their high potential subordinates?}

The remainder of the article is structured as follows. It begins with literature related to high potentials and global leadership. Next, the role of line managers in developing leadership competencies of subordinates is discussed as the basis upon which contextualized and detailed research hypothesis is developed. Thereafter, the conceptualization is presented. The procedure of the study and the measurement of constructs are subsequently stated, followed by a discussion of the population and the sample. Then, the data analyses process is explained, and the findings are discussed. Implications from our research study are explained afterward. Paper ends with directions for further research and concluding remarks.

\section{LITERATURE REVIEW}

\subsection{Developing high potentials as global leaders in MNCs}

With the enormous changes taking place in the global business environment, the leadership competencies that were of paramount importance in the corporate leadership profiles have become obsolete and inappropriate for the new business paradigm (Mendenhall, 2000; Storey, 2016). Hence, it is very much important to have the leaders in MNCs with the right kind of competencies to drive the businesses towards success amidst turbulence (Black et al., 2013) by getting the right type of leaders on board. Many studies (e.g., Mendenhall, 2000; Perlmutter, 2017) have found that though it is impossible to exactly identify the 'right' kind of leaders suitable to meet the demands of this corporate evolution, organizations must prepare their leaders in a global capacity. The MNCs today must prepare future leaders who can successfully execute a global corporate strategy (e.g., deal with complex organizational structures) by demonstrating cross-cultural leadership competencies (e.g., who can deal with people from different nationalities, work in different countries) (Deresky, 2017; Mendenhall, 2000). According to the Global Leadership Forecast 2011 (Boatman and Wellins, 2011), organizations with global leaders were likely to outperform their competition 13 times more in key bottom-line metrics. Hence, based on literature it is clearly evident that organizations need to strongly emphasize developing global leadership talent among the limited pool of high potentials in their organizations. As global competition is rapidly becoming the norm in which all business organizations must compete in one fashion or another, MNCs need to pay serious attention to creating worldclass/global leaders to face the competition heightened by globalization.

Literature related to Human Resource Management (HRM) practices in MNCs fall under the domain of International HRM (IHRM). Though previously the subject of IHRM focused only about how traditional HR functions differ when it comes to MNCs, more recently the definition of strategic IHRM has expanded to include localization of management and global leadership development (Collings, 2014). This further confirms the increased attention on developing world-class global leaders in MNCs. During the recent global economic recessions, many MNCs were guilty of losing their focus on talent, as they focused on reducing costs to save businesses. Those MNCs are now experiencing the consequences of such actions as they struggle in the recovery process due to not having the leaders of needed capacity for today and more importantly, for the future (Becerra-Fernandez and Sabherwal, 2014; Boatman and Wellins, 2011). The same authors further emphasize the need of developing global leaders referring to earlier editions of the Global Leadership Forecast, which mention that the strength of people prepared to take leadership in organizations in the future is alarmingly weak as the progress 
in improving leadership has been stagnant for far too long. While presenting this, they highlight that the time has come to revolutionize leadership practices in organizations to develop global leadership competencies in high potentials to keep up with the speed of business. In the present business setup, all these evidence show the need to pay attention to developing high potentials into global leaders, for MNCs to successfully navigate in the $21^{\text {st }}$ Century.

Osland (2013) identify that a majority of MNCs have developed global leadership competency profiles as they have understood the need of globally competent leaders in their efforts to build and sustain the talent pipeline. Accordingly, some MNCs tend to and the others need to, match the employees in talent pools with their global leadership competency profiles and focus their leadership development initiatives accordingly. As a result, most MNCs have taken measures to get their subsidiaries to recognize the global headquarters' leadership imperatives as the benchmark (Ansari et al., 2014; Chugh and Bhatnagar, 2006). Those imperatives describe about developing employees into global leaders who can work anywhere in the world facing environmental turbulence successfully. However, most MNCs and their subsidiaries often incur vacancies in global positions and they find it hard to get suitably qualified people to fill those vacancies. Though MNCs have the options of either recruiting externally or promoting internally, they prefer internal promotions (Akey et al., 2016) and therefore, it is important to pay attention to developing global leaders who match with the headquarters' leadership imperatives, from the high potential talent pools. High potentials are employees demonstrating a high contribution, strong organizational values, potential to move up within a given period, and assume greater responsibility in the future (Fairney, 2010). They exhibit a history of highperformance and are expected to demonstrate leadership potential.

\subsection{Role of line managers in developing leadership competencies of subordinates}

Though the HR Departments of MNCs take a lot of efforts in developing employees to take up leadership positions in the future by even appointing a separate manager for leadership development (e.g., Unilever Sri Lanka etc.); and conducting 'High Potential Leadership Development Programs' for future leaders at each work level under learning and development efforts, the MNCs are strongly of the opinion that the line managers play a crucial role in their subordinate leadership development. The degree to which every supervisor takes this responsibility will have a tremendous impact upon the collective leadership development in MNCs. This goes in line with the idea that every manager is an HR manager irrespective of their functional specialization.

Grooming subordinates to take up leadership is identified not as just a task in the Job Description (JD) of managers with subordinates under them, but as one of their major responsibilities, in every organization. However, it is not an easy task for traditional autocratic leaders. Many organizations have clearly set up subordinate development as a supervisory responsibility in top-level doctrine (Clinton, 2018). Hence, organizations today have included follower leadership development as a performance evaluation criterion of managers, though this has not been well implemented. This may be because, line managers do not get sufficient inputs on their behavior as leaders (Fernández-Aráoz et al., 2011). Leaders are not stepping up to the responsibility of developing their followers unless there is a corporate backing, as some are reluctant that the followers will become better leaders than them. Traditional managers look at highly talented subordinates as a threat who could replace them (Diefenbach and Sillince, 2012) and thus, is scared of a possible layoff. Under follower leadership development, the leaders should help the followers to develop their own initiative, strengthen them to use their own judgment, enable them to grow, and become better contributors to the organization (Nielsen and Daniels, 2012). This kind of challenging work experience is important in leadership development, as in the practical context, experiences gained through day-to-day work under the supervisors provide better development, than educational opportunities. Considering the above, there are sufficient implications in literature to argue that the supervisors of high potentials, who are often middle or senior managers of MNCs have a major role in developing their high potential subordinates into global leaders. 
In leadership literature (e.g., Bass, 1985; Dionne et al., 2004; Kovjanic et al., 2012) it is found that the leaders who contribute towards the development of followers are leaders with transformational leadership dimensions. They contribute most to the positive outcomes among followers. Day et al. (2014) also confirm this statement, stating that the principal aspect of transformational leadership is the emphasis on follower development, while Kovjanic et al. (2012) state followers' needs are the main focus in transformational leadership. Yukl (1999) states that transformational leaders can influence followers to make self-sacrifices, commit to difficult goals, and achieve more than initially expected, and ultimately develop themselves into leaders. It is possible to extend this notion on transformational leadership and follower development and argue that if the line manager is a transformational leader, he/she would contribute to making their high potential subordinates into global leaders in the MNC context. Though there are studies that have discussed the role of leaders on follower development, there are no studies found extending this notion to global leadership development in the MNC context and thus, the present study contributes to that void in the literature.

2.3. Transformational leaders and developing global leadership competencies of high potentials Out of an array of factors contributing to global leadership development, the role of the line manager is emphasized in this study. Concise Oxford English Dictionary defines a line manager/supervisor as a person with direct managerial responsibility for an employee. In this study, the term line manager refers to the immediate supervisor or the reporting manager of the high potential employee.

Many studies (e.g., Dumdum et al., 2013; Boehm et al., 2015) have identified the potential of transformational leaders to transform their subordinates into future leaders in an organization. In a similar vein, it could be proposed here that transformational managers would contribute largely to develop global leadership competencies of their high potential subordinates in the MNC context. With the greater need of MNCs to develop global leaders, it is possible to argue based on the transformational leadership theory (Burns, 1978), that having line managers with transformational leadership would create global leaders in the MNC context.

The transformational leadership theory, which is also referred to as the developmental leadership model, is supported by the work of Bass (1985), Avolio et al. (2009), Dvir et al. (2002), Conger and Kanungo (1988), Kark and Shamir (2002), Tichy and DeVanna (1986; 1990), and many others. According to the theory, the leadership behaviors of transformational leaders change the thinking and inspire followers to perform beyond expectations while rising above their self-interests, for the good of the organization. The theory suggests that transformational leaders raise followers' aspirations and activate their higher order values (e.g., altruism, collectivism, in-group loyalty) such that the followers identify with the leader and his or her mission/vision, feel better about their work, and then work to show greater performance (Chordiya et al., 2017). In addition, the theory also suggests that transformational leaders contribute to follower leadership development and convert followers into leaders (Bass, 1985). These leaders create a change within followers by transforming their attitudes, beliefs, and values as opposed to simply gaining compliance, and thus followers tend to develop their own leadership capacity and perform with a passion in the business (LePine et al., 2016). Because of this differential focus, transformational leadership theory has turned out to be the most frequently researched leadership theory over the past years (Dinh et al., 2014).

Although considerable progress has been made in studying transformational leadership, via the transformational leadership theory, several areas still deserve further attention and discussion (Avolio and Yammarino, 2013). For example, though it is confirmed that transformational leaders contribute to follower leadership development; there is a dearth of research that extends this argument to different corporate contexts. Taking that lacuna in research into consideration, this study attempts to extend the main argument of the transformational leadership theory into the context of global leadership development in the MNC context. As MNCs suffer from a scarcity of global leaders, it is important to have senior managers on board, who can develop the followers into the kind of leaders demanded by 
the business. Transformational leaders are ideal in this scenario as they influence the perceptions, cognitions, decisions, and behaviors of their subordinates (Bass, 1985). The transformational leader inspires, intellectually stimulates, and individually considers about the followers and their performance (Breevaart et al., 2016). Such behaviors of transformational leaders would transform the high potentials in the MNC context, to reach their full potential and produce the highest level of leadership performance. According to the transformational leadership theory, transformational leaders empower followers by giving due recognition and appreciation for their work and develop their competencies to reach the full potential (Bass, 1985). This view of Bass implies that transformational managers could stretch the high potential subordinates to reach their maximum capacity, could it be in job performance or demonstrating leadership competencies. Transformational leaders evaluate the potential of their followers in terms of their ability to fulfill current commitments and in the case of high potentials who need to be groomed as future leaders, the leaders envision on expanding their responsibilities. Then, the followers would make better global leaders in the future leading themselves and others and meeting the demands in the MNC context.

Based on the above theoretical and empirical support, the following hypothesis is established to be tested.

\section{$H_{1}$ : There is an impact of line managers' transformational leadership on global leadership competencies of high potential subordinates}

The next section will present the methodology used to test the above hypothesis.

\section{METHOD}

\subsection{Procedure}

This study is conducted following the quantitative method and the deductionist approach as an explanatory research. The study is based on primary data collected using a self-administered, anonymous, structured questionnaire developed using standard measures and thus, the survey strategy is the best suited. Since the study is done by collecting data at one point in time it is considered a crosssectional study. The unit of analyses is dyads - the high potential subordinate and his or her respective supervisor, from whom the sample comprised of. The data were collected through an emailed Google ${ }^{\circledR}$ form or by delivering and collecting questionnaires. Data on line managers' transformational leadership were collected from their high potential subordinates' in Questionnaire A. Global leadership competencies of high potentials were measured in Questionnaire B, filled by the respective line managers. Finally, the demographic information was obtained from both parties, as ensuring external validity of a study requires descriptive data on the basic demographic profile of the sample (Kallet, 2004). The questionnaire was arranged in a manner where data on the two key constructs was collected initially and the personal information about the respondent was collected later. Data collection took approximately $2 \frac{1}{2}$ months where 187 dyads responded with a response rate of $62 \%$. Out of the 187 questionnaires received, only 158 were usable, thus, considering the usable questionnaires, the return rate is $53 \%$.

\subsection{Measures}

Author used available standard measures to measure the two main constructs of the study. The 41item, multi-dimensional scale included in 'The Evolving Role of Executive Leadership' study undertaken by Accenture (2001), with the purpose of developing a 'Profile of the Global Leader of the Future', was used to assess the global leadership competencies of high potential employees. Scale scores ranged along a 7-point rating scale from 1 ('strongly disagree') to 7 ('strongly agree'), where higher scores indicated a higher level of global leadership competencies. Operationalization of transformational leadership presented by Bass and Avolio (1990) covering the four main dimensions (four 'I's - (a) idealized influence - attributed and behavioral charisma, (b) inspirational motivation, 
(c) intellectual stimulation, and (d) individualized consideration) of transformational leadership is used in this study. Accordingly, the measure used by Hinkin and Tracey (1999), comprising of 39-items from Form 5-X of the Multi-factor Leadership Questionnaire (MLQ), is used to measure line manager's transformational leadership.

In addition to the two main variables in the model, dyadic tenure is considered as a control variable based on literature.

The next section explains the population and the sample of the study.

\subsection{Sample}

The population of this study are all high potential employees in the middle managerial level in MNC subsidiaries operating in Sri Lanka and their respective supervisors. The sample of the study is nonprobabilistic even though the survey strategy is chosen, since the respondents were selected based on the accessibility and willingness to participate in the survey (i.e. convenience sampling) as it is not possible to specify a sample frame, thereby making it difficult to estimate the probability of including each element in the sample (Polit and Beck, 2009; Saunders et al., 2011; Schutt, 2006).

Out of the dyadic sample of 158 , most (39.2\%) of the high potentials belong to the age category of 30 40 years. There are $56 \%$ male and $44 \%$ female high potentials in the sample. The majority (36.7\%) of the high potentials have worked in their organizations for 3-5 years. A larger percentage of them (42\%) have been in their current job for 3-5 years. Many of the high potentials have been with their respective bosses for 1-2 years. All high potentials in the sample are Sri Lankans. The highest percentage of line managers in the sample belong to the age category of 41-50 years. There are more male line managers than females. Majority of the line managers (76) have been with the organization for 3-5 years. The most number (69\%) of line managers have been in their present job for 3-5 years.

\section{DATA ANALYSES AND RESULTS}

This section presents the data analyses done using SPSS and AMOS 23.0 softwares.

Before performing the hypothesis testing, the preliminary analyses were performed, and this included data screening and ensuring reliability and validity. Accordingly, missing data were treated, and data were tested for normality, linearity, and homoscedasticity. Content and criterion-related validity of the data are ensured as validated, standard measures were used to measure the two main constructs and construct validity which comprises of convergent and discriminant validity were ensured by performing a Confirmatory Factor Analysis (CFA) using AMOS and by calculating the AVE value and developing a discriminant validity matrix. Inter-item consistency reliability was ensured by calculating Cronbach's alpha and the values are .98 for both variables. There is a moderate positive correlation (.58) between transformational and global leadership. In addition, Harman's Single Factor test was also performed to confirm that there is no Common Method Variance present and therefore no statistical remedies were required.

The mean, Standard Deviation (SD), correlation, and reliability statistics related to the two variables are shown in Table 1 below.

Table 1: Descriptive statistics and output of the basic preliminary analysis

\begin{tabular}{lcccc}
\hline Variable & Mean & SD & Correlation & Reliability \\
\hline Global Leadership & 3.76 & 1.25 & & 0.98 \\
Transformational Leadership & 3.88 & 1.34 & .58 & 0.98 \\
\hline
\end{tabular}


Next, the hypothesis testing is performed using the first-generation confirmatory data analysis techniques. Accordingly, as this study is testing for an impact and as there is one predictor and one control variable multiple regression analysis- hierarchical regression or block wise entry is used (Field, 2009). As emphasized by Hair et al. (2018) the independent and the dependent variable are metric and thereby qualify to use multiple regression analysis. However, the control variable 'dyadic tenure,' is a non-metric variable representing an ordinal measurement scale, thus, is transformed with dummy coding as specified by Hair et al. (2018) to make it suitable to be used in Multiple Regression Analysis.

Accordingly, the second category (1-2 years) which has the greatest number of responses in the datasheet, is considered the baseline taking guidance from Field (2009), and four dummy variables are created to match the five response categories.

In running the regression analysis, the summated means of responses for each construct is used. There was a positive correlation between the variables, thus the gradient of the regression equation testing the hypothesis is positive. The $b_{0}$ in the regression equation denotes the level of global leadership competencies possessed by high potentials when predictor in the equation is absent. This is possible as all the sample members are high potentials. A hierarchical multiple regression is performed to test the impact of line managers' transformational leadership on global leadership competencies of high potentials, by entering the dummy variables of dyadic tenure in block one and line managers' transformational leadership in block two. The standardized beta $(\beta)$ for transformational leadership indicates if the effect of the control variable is held constant, there is a positive impact of line managers' transformational leadership on global leadership competencies of high potentials, and the degree it affects global leadership competencies of high potentials is 0.51 . This indicates that when the transformational leadership of line managers' increase by one standard deviation, global leadership competencies of high potentials increase by 0.51 standard deviations when dyadic tenure is held constant. In addition, the probability of the $t$-statistic (8.41) for the standardized beta $(\beta)$ coefficient of the independent variable is significant $(0.00<0.01)$. Statistics relating to the regression are depicted in Table 2. "The smaller the value of Sig. (and the larger the value of $t$ ), the greater the contribution of that predictor" (Field, 2009). As there is a statistically significant contribution from line managers' transformational leadership towards global leadership competencies of high potentials, the hypothesis is supported by the data.

Dyadic tenure alone accounts for $20 \%$ of the variance in global leadership competencies of high potentials as explained by $R^{2}$ in Model 1 in Table 2. Similarly, if the model had been derived from the population, dyadic tenure would account for $19 \%$ of the variance in global leadership competencies of high potentials as indicated by adjusted $R^{2}$ in Model 1. In Model 2, 45\% of the variance in global leadership competencies of high potentials is accounted for by the regression model from the sample. $44 \%$ of the variance in global leadership competencies of high potentials is accounted for by the model had it been derived from the population. The model indicates that $25 \%$ of the variance in global leadership competencies of high potentials is explained by transformational leadership alone. $F$ statistic indicates the significance of $R^{2}$ and as the $F$ change for both models 1 and 2 are significant at .01 level, it can be concluded that the addition of transformational leadership has increased the predictability of the model significantly.

Table 2: Model parameters and model summary

\begin{tabular}{lcccccc}
\hline Variables & & $\begin{array}{c}\text { Model 1 } \\
\mathbf{~}\end{array}$ & Sig. & $\boldsymbol{\beta}$ & $\begin{array}{c}\text { Model 2 } \\
\mathbf{t}\end{array}$ & Sig. \\
\hline Control Variables & & & & & & \\
Dyadic Tenure (yrs) & & & & & & \\
$\quad<01$ & -0.23 & -2.99 & 0.00 & -0.20 & -3.08 & 0.00 \\
$3-5$ & 0.32 & 4.17 & 0.00 & 0.22 & 3.43 & 0.00 \\
\hline
\end{tabular}




\begin{tabular}{|c|c|c|c|c|c|c|}
\hline $6-10$ & 0.09 & 1.17 & 0.25 & 0.08 & 1.36 & 0.18 \\
\hline \multicolumn{7}{|l|}{ Independent Variable } \\
\hline Transformational Leadership & & & & 0.51 & 8.41 & 0.00 \\
\hline \multicolumn{7}{|l|}{ Model Summary Statistics } \\
\hline$R$ & & 0.45 & & & 0.67 & \\
\hline$R^{2}$ & & 0.20 & & & 0.45 & \\
\hline Adjusted $R^{2}$ & & 0.19 & & & 0.44 & \\
\hline$\Delta R^{2}$ & & 0.20 & & & 0.25 & \\
\hline$\Delta F$ & & 12.95 & & & 70.65 & \\
\hline Sig. $\Delta F$ & & 0.00 & & & 0.00 & \\
\hline
\end{tabular}

\section{DISCUSSION}

Firstly, the study was conducted to examine, why high potential employees do not become better global leaders once they take up leadership positions in subsidiaries of MNCs. In addressing that, the study looked at how transformational leadership of line managers contributes to predicting the global leadership competencies of high potentials reporting to them. Results indicate that line managers' transformational leadership has a significant positive impact $\left(R^{2}=0.45, p=.000\right)$ in developing the global leadership competencies of high potentials. The hypothesis was established based on previous empirical evidence giving greater emphasis to the line manager regarding follower leadership development. Based on leadership literature (e.g., Bass, 1985; Burns, 1978) and according to the transformational leadership theory, the study focused on transformational leadership of the line manager, as one of the major characteristics of transformational leaders is follower development, and it is not only mere development but developing them to become future leaders (Qu et al., 2015; Yukl, 1999). In line with those studies, the present study also confirms that line managers' transformational leadership has a major impact on developing leadership competencies of subordinates.

Secondly, the selection of transformational leadership of the line manager as the independent variable is further justified, given the context in which the study was performed. Transformational leadership is most effective in environments of great transformational changes, with the absence of stability, and greater insecurity. Transformational leadership boosts the development of followers, challenging them to think in novel ways which they were not accustomed to thinking previously, stimulating them to accomplish beyond what they normally felt was possible, and motivating them to do so while keeping the values and high moral standards that guide them in mind (Caniëls et al., 2018). This confirms the necessity of transformational leadership for leadership development, given the congruence between the environments suggested in the literature for transformational leadership to be effective and the environment in MNCs. MNC settings are shaped by both technological change and commercialization worldwide (Monteiro, 2015). Accordingly, based on prior evidence confirming the congruence between the MNC setting and the setting in which transformational leadership will be effective, the present study suggests transformational leaders would contribute to developing their high potential subordinates into global leaders, as it is important to develop global leaders according to the requirements of MNCs.

Descriptive statistics confirm the existence of the problem addressed through the study showing a low level $($ mean $=3.76$ ) of global leadership competencies among high potentials. Many organizations state that lack of leadership talent is back holding their business and that those organizations are considering improving leadership skills as their top priority in the years to come (Bersin and Associates, 2011). This confirms the currency of the study, being in line with the pressing need in the corporate world to develop the needed type of leaders. As suggested in this study, a salient reason for this low global leadership among high potentials is, low (mean $=3.88$ ) transformational leadership of their respective line managers. 
This outcome can also be applied to a broader setting. Though the settings will not be the same, the findings can be applicable to the subsidiaries of MNCs located in other countries and to the large local organizations operating in Sri Lanka. The research methodology, the data analyses techniques, and selecting a sample of high potentials across industries increase the generalizability of the findings. Though there are differences between organizations selected, as MNC subsidiaries they have a lot of similarities despite a few cultural differences resulting from the culture in the parent company and the county, and those similarities contribute to the generalizability of the findings.

\section{CONCLUSION AND IMPLICATIONS}

The study makes an immense contribution to the theoretical and empirical knowledge base on managing high potentials, as it looks at the unpreparedness of the high potentials to take over top leadership positions, which is an area that demands serious attention of academic researchers. The present study is undertaken at a time where the number of studies reported on high potentials in the Sri Lankan context is very limited. The study belongs to a variety of domains and contributes to the knowledge in the areas of talent management, leadership, and International HRM. Mendenhall et al. (2017) have emphasized the importance of the collaborative use of disciplines to produce a new model of global leadership development and the present study responds to that claim. Leadership has been an important topic in Social Sciences for decades but has gained greater popularity nowadays with the recent renewed interest on it among practitioners and the academia (Dinh et al., 2014). Despite the richness of literature in the area of leadership, there is a need for more systematic research on micro concepts within the broad leadership domain such as global leadership, leadership development etc. (Reiche et al., 2017). A unique feature in this study is, it extends the idea that transformational leaders contribute to follower leadership development in transformational leadership theory to the context of global leadership development in MNCs.

In a situation where a new type of corporate leaders is emerging due to globalization, namely the global leaders (De Meuse et al., 2005), the accumulated knowledge base on global leadership, as well as the volume of ongoing global leadership research, is surprisingly limited compared to its importance (Mendenhall et al., 2017). Hence, this study will add an essential bit of knowledge to this emerging concept. Furthermore, the study lays the foundation for further empirical work in the areas of talent management and global leadership. By establishing a relationship between line managers' transformational leadership and global leadership competencies of high potentials, the present study goes beyond the traditional notion of leader development through training (Day, 2001), to emphasize the less noticed role of the boss in follower leadership development. The need to develop effective leaders with adequate competencies has become obvious in recent years (Morrison, 2000; Jokinen, 2005). In the current century, companies, especially including MNCs, are seriously considering about leadership competencies of their employees as a source for competitive advantage and sustainable strategic development. This focus of MNCs is addressed in this study. Through the study, it is expected to provide insight to get away from the traditional understanding that leadership training using traditional methods of delivery is the only solution for the shortage of leadership in organizations. In addition, this study also alarms about the need to move away from the thinking that, the role of developing and training people solely lies with the HR and HRD managers in organizations, by emphasizing about the greater responsibility that lies in the hands of supervisors. According to Weerakkody (2011), line managers have contributed 39\% to the exit of key talent from organizations in the Sri Lankan and Asian context, justifying the need to look at the issues related to high potentials caused by line managers. It indicates the impact that a supervisor could have on a subordinate, which is possible to extend to leadership development.

There is a novelty in the research context of this study, as studies done on MNCs in Sri Lanka are very limited and at the same time, leadership studies done in such a context are also not available. Though 
there is a certain amount of leadership research conducted in Sri Lanka, they are done in local organizations and MNCs are often less addressed in research in Sri Lanka.

Further to its theoretical contribution, the study contributes to the practice of HRM in the MNC context (IHRM), talent management, Human Resource Development (HRD), and leadership. The study provides insight on leadership development in organizations, especially focusing on planning leadership development programs. According to this study, in addition to the high costs incurred on training programs organized by the HR Departments with the support of trainers, extensive leadership development can be done during the day-to-day course of work by line managers at no cost.

\subsection{Limitations of the study}

Despite the study's contributions, as is the case with all the research work, this study encountered several limitations. In addition to using the questionnaire method, there are other methods of data collection within the survey strategy, which were not implemented in this study due to the limited time and restrictions from MNCs (Zikmund, 2010). The design of the study is correlational and crosssectional in nature. The use of cross-sectional data collected at one point in time raises the concern of potential common method bias as it artificially inflates the correlation among the independent and the dependent variable (Podsakoff et al., 2003). The relationship would have been better tested if the global leadership competencies of high potentials were tested once and then evaluated after they work under leaders with transformational leadership for a period. But as pointed out by Van Vianen et al. (2011), practical obstacles in field settings such as loss of response over time and problems with the sustained cooperation of organizations prevented doing such a longitudinal study. i.e. this results from a trade-off between the scientific standard and the research constraints of collecting data from this type of organizations with global operations (Giauque et al., 2016). Apart from that, the study does not have a sampling frame and the sample does not contain an equal representation from all industries. As convenience sampling was used, there is an underrepresentation of companies in certain industries in the sample. However, this was due to the official policies among certain firms to not expose their high potentials to participate in research (Sheehan, 2012).

Despite the limitations, the techniques used in data collection and analyses also enhance the quality of the findings (e.g.; procedural remedies taken to eliminate CMV). This is a major strength of the study as it thereby eliminates a salient weakness associated with field studies (Wat and Shaffer, 2003). The research context of this study is not used by many researchers and with the increasing investments by foreign companies in Sri Lanka after the war; this kind of knowledge generation may appear very much useful.

\subsection{Directions for further research}

This study is an initial attempt to look at MNC leadership development and more theoretical and empirical work by Sri Lankan researchers is clearly needed in the area. Though leadership had been an attractive and important topic for research, there are many areas within it which are less explored. There are many areas for exploration especially with the emphasis of organizations to develop global leaders, to meet the pressures of globalization. Further, it is important to look at other factors which contribute to global leadership development in organizations. Thus, it would merit to look at factors like organizational culture, mentoring and coaching programs, leader's personality, cross-cultural training, family background, empowerment practices of managers, and international assignments as possible predictors of global leadership development in future research. Another broad factor that could be addressed is the impact of HR practices of MNCs on developing global leadership competencies of high potentials. It would cover most of the areas suggested above and thereby provide the impact of each HR practice on developing the global leadership competencies of employees of MNCs. 
As in Khatri and Duggal (2011), Bass has suggested that leaders can simultaneously display transformational and transactional leadership, and based on that view, if the future researchers can bring together both the transformational and transactional leadership of line managers or the full range of leadership (Bass, 1997) as the independent variable of this study, using a measure like the MultiFactor Leadership Questionnaire (MLQ), the quality of the study could be further enhanced.

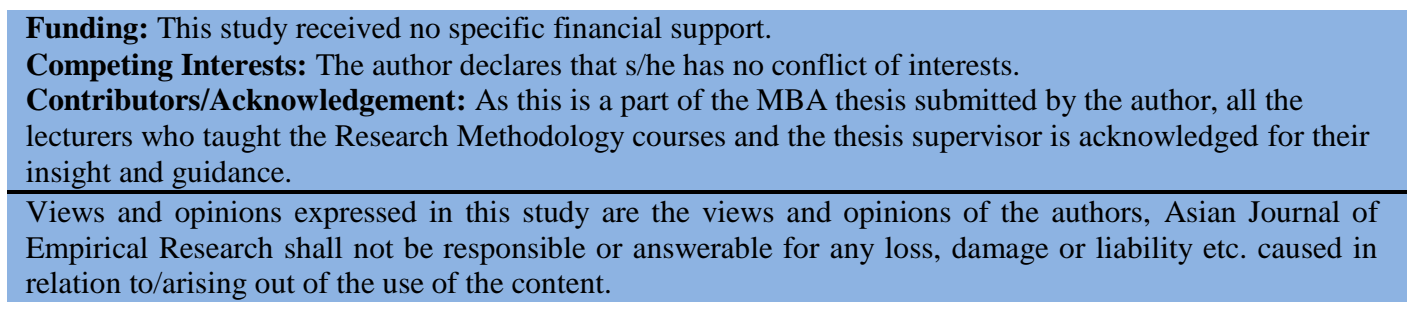

\section{References}

Accenture Institute for Strategic Change. (2001). The evolving role of executive leadership. Accenture.

Akey, B. C. A., Jiang, X., Antwi, H. A., \& Torku, E. (2016). Evolution of Diversity Management Initiatives Among Multinational Firms: Lessons from Developing Economies', International Journal of Scientific Research in Science. Engineering and Technology (IJSRSET), 2(6), 489497. Available at: http://ijsrset.com/paper/2105.pdf.

Al Ariss, A., Cascio, W. F., \& Paauwe, J. (2014). Talent management: Current theories and future research directions. Journal of World Business, 49(2), 173-179.

Ansari, S., Reinecke, J., \& Spaan, A. (2014). How are practices made to vary? Managing practice adaptation in a multinational corporation. Organization Studies, 35(9), 1313-1341.

Association for Human Resources Management in International Organizations. (2010). Leadership \& talent development in international organizations. Retrieved from http://www.futureworkforum.com/PDFs/Leadership_Talent_\%20Jan_2010.pdf .

Avolio, B. J., \& Yammarino, F. J. (Eds.). (2013). Introduction to, and overview of, transformational and charismatic leadership. In Transformational and Charismatic Leadership: The Road Ahead 10th Anniversary Edition (pp. 27-33). Emerald Group Publishing Limited.

Avolio, B. J., Walumbwa, F. O., \& Weber, T. J. (2009). Leadership: Current theories, research, and future directions. Annual Review of Psychology, 60, 421-449.

Bass, B. M. (1985). Leadership and performance beyond expectations. New York: Free Press.

Bass, B. M. (1997). Does the transactional-transformational leadership paradigm transcend organizational and national boundaries? American Psychologist, 52(2), 130-139.

Bass, B. M., \& Avolio, B. J. (1990). The implications of transactional and transformational leadership for individual, team, and organizational development. Research in Organizational Change and Development, 4, 231-232.

Beamond, M. T., Farndale, E., \& Härtel, C. E. (2016). MNE translation of corporate talent management strategies to subsidiaries in emerging economies. Journal of World Business, 51(4), 499-510.

Becerra-Fernandez, I., \& Sabherwal, R. (2014). Knowledge management: Systems and processes. Routledge.

Bersin, J., \& Associates. (2011). Talent Watch Q1 2011-Global growth creates new war for talent. Oakland, CA: Bersin \& Associates.

Bird, A., \& Mendenhall, M. E. (2016). From cross-cultural management to global leadership: Evolution and adaptation. Journal of World Business, 51(1), 115-126.

Black, J. S., Morrison, A. J., \& Gregersen, H. B. (2013). Global explorers: The next generation of leaders. Routledge. 
Boatman, J., \& Wellins, R. S. (2011). global leadership forecast 2011: time for a leadership revolution. Retrieved from http://www.ddiworld.com/DDIWorld/media/trendresearch/globalleadershipforecast2011_globalreport_ddi.pdf.

Boehm, S. A., Dwertmann, D. J., Bruch, H., \& Shamir, B. (2015). The missing link? Investigating organizational identity strength and transformational leadership climate as mechanisms that connect CEO charisma with firm performance. The Leadership Quarterly, 26(2), 156-171.

Breevaart, K., Bakker, A. B., Demerouti, E., \& Derks, D. (2016). Who takes the lead? A multi-source diary study on leadership, work engagement, and job performance. Journal of Organizational Behavior, 37(3), 309-325.

Burns, J. M. (1978). Leadership. New York: Harper \& Row.

Caniëls, M. C., Semeijn, J. H., \& Renders, I. H. (2018). Mind the mindset! The interaction of proactive personality, transformational leadership and growth mindset for engagement at work. Career Development International, 23(1), 48-66.

Chordiya, R., Sabharwal, M., \& Goodman, D. (2017). Affective organizational commitment and job satisfaction: A cross-national comparative study. Public Administration, 95(1), 178-195.

Chugh, S., \& Bhatnagar, J. (2006). Talent management as high performance work practice: Emerging strategic HRM dimension. Management and Labor Studies, 31(3), 228-253.

Clinton, R. (2018). The making of a leader: Recognizing the lessons and stages of leadership development. Tyndale House Publishers, Inc.

Collings, D. G. (2014). Integrating global mobility and global talent management: Exploring the challenges and strategic opportunities. Journal of World Business, 49(2), 253-261.

Conger, J. A., \& Kanungo, R. N. (1988). The empowerment process: Integrating theory and practice. Academy of Management Review, 13(3), 471-482.

Day, D. V., Fleenor, J. W., Atwater, L. E., Sturm, R. E., \& McKee, R. A. (2014). Advances in leader and leadership development: A review of 25 years of research and theory. The Leadership Quarterly, 25(1), 63-82.

Day, D. V. (2001). Leadership development: A review in context. Leadership Quarterly, 11(4), 581613.

De Meuse, K. P., Tang, K. Y., \& Mlodzick, K. J., \& Dai, G. (2005). The world is flat ... and so are leadership competencies. Retrieved from http://www.kornferryinstitute.com/sites/all/files//documents/briefings-magazinedownload/The\%20World\%20is\%20FlatAnd\%20so\%20are\%20Leadership\%20Competencies \%20.pdf.

Deresky, H. (2017). International management: Managing across borders and cultures. Pearson Education India.

Diefenbach, T., \& Sillince, J. A. A. (2012). Crossing of Boundaries - Subordinates' Challenges to Organizational Hierarchy. In T. Diefenbach \& R. T. By (Eds.), Reinventing Hierarchy and Bureaucracy - from the Bureau to Network Organizations (pp. 171-201). Emerald Group Publishing Limited. Retrieved from https://www.emeraldinsight.com/doi/abs/10.1108/S0733$\underline{558 X \% 282012 \% 290000035009}$

Dinh, J. E., Lord, R. G., Gardner, W. L., Meuser, J. D., Liden, R. C., \& Hu, J. (2014). Leadership theory and research in the new millennium: Current theoretical trends and changing perspectives. The Leadership Quarterly, 25(1), 36-62.

Dionne, S. D., Yammarino, F. J., Atwater, L. E., \& Spangler, W. D. (2004). Transformational leadership and team performance. Journal of Organizational Change Management, 17(02), 177-193.

Dumdum, U. R., Lowe, K. B., \& Avolio, B. J. (2013). A meta-analysis of transformational and transactional leadership correlates of effectiveness and satisfaction: An update and extension. In Transformational and Charismatic Leadership: The Road Ahead 10th Anniversary Edition (pp. 39-70). Emerald Group Publishing Limited. 
Dvir, T., Eden, D., Avolio, B. J., \& Shamir, B. (2002). Impact of Transformational Leadership on Follower Development and Performance: A Field Experiment. Academy of Management Journal, 45(4), 735-744.

Fairney, J. S. (2010). An examination of succession management in organizations during times of economic crisis. Pepperdine University.

Fernández-Aráoz, C., Groysberg, B., \& Nohria, N. (2011). How to hang on to your high potentials. Harvard Business Review, 89(10), 76-83.

Field, A. (2009). Discovering statistics using SPSS (3rd ed.). London: Sage Publications.

Giauque, D., Anderfuhren-Biget, S., \& Varone, F. (2016). Stress and turnover intents in international organizations: social support and work-life balance as resources. The International Journal of Human Resource Management, 1-23, doi:10.1080/09585192.2016.1254105.

Gurdjian, P., Halbeisen, T., \& Lane, K. (2014). Why leadership-development programs fail. McKinsey Quarterly, 1(1), 121-126.

Hair, J. F., Black, W. C., Babin, B., \& Anderson, R. E. (2018). Multivariate data analysis (8th ed.). Cengage. Retrieved from https://www.amazon.com/Multivariate-Analysis-William-authorAnderson/dp/1473756545/ref=dp_ob_title_bk.

Hinkin, T. R., \& Tracey, J. B. (1999). The relevance of charisma for transformational leadership in stable organizations. Journal of Organizational Change, 12(2), 105-119.

Jokinen, T. (2005). Global leadership competencies: A review \& discussion. Journal European Industrial Training, 29(3), 199-216.

Kallet, R. H. (2004). How to write the methods section of a research paper. Respiratory Care, 49(10), 1229-1232.

Kark, R., \& Shamir, B. (2002). The dual effect of transformational leadership: Priming relational and collective selves and further effects on followers. Transformational and charismatic leadership: The road ahead, 2, 67-91.

Khatri, P., \& Duggal, S. (2011). A test of transactional and transformational leadership behavior of salesman on customer relationship marketing behavior: A study of the Indian Banking sector. BVICAM's International Journal of Information Technology (BIJIT), 4(1), 37-44.

Kovjanic, S., Schuh, S. C., Jonas, K., Quaquebeke, N. V., \& Van Dick, R. (2012). How do transformational leaders foster positive employee outcomes? A self-determination-based analysis of employees' needs as mediating links. Journal of Organizational Behavior, 33(8), 1031-1052. doi: 10.1002/job.1771.

LePine, M. A., Zhang, Y., Crawford, E. R., \& Rich, B. L. (2016). Turning their pain to gain: Charismatic leader influence on follower stress appraisal and job performance. Academy of Management Journal, 59(3), 1036-1059.

Mendenhall, M. E. (2000). New perspectives on expatriate adjustment and its relationship to global leadership development. In M.E. Mendenhall, T. M. Kuhlman, \& G.K., Stahl (Eds), Developing global leaders: Policies, processes, and innovations. Westport, CT: Quorum.

Mendenhall, M. E., Osland, J., Bird, A., Oddou, G. R., Stevens, M. J., Maznevski, M., \& Stahl, G. K. (Eds.). (2017). Global leadership: Research, practice, and development. Routledge.

Monteiro, L. F. (2015). Selective attention and the initiation of the global knowledge-sourcing process in multinational corporations. Journal of International Business Studies, 46(5), 505-527.

Morrison, A. J. (2000). Developing a global leadership model. Human Resource Management, 39(23), 117-131.

Nielsen, K., \& Daniels, K. (2012). Does shared and differentiated transformational leadership predict followers' working conditions and well-being? The Leadership Quarterly, 23(3), 383-397.

Osland, J. S. (2013). An overview of the global leadership literature. In Global Leadership 2e (pp. 5291). Routledge.

Osland, J. S. (2017). Global leadership. The international encyclopedia of intercultural communication, 1-6.

Perlmutter, H. V. (2017). The tortuous evolution of the multinational corporation. In International Business (pp. 117-126). Routledge. 
Podsakoff, P. M., MacKenzie, S. B., Lee, J. Y., \& Podsakoff, N. P. (2003). Common method biases in behavioral research: A critical review of the literature and recommended remedies. Journal of Applied Psychology, 88(5), 879-903.

Polit, D. \& Beck, C., (2009). Nursing research: Appraising evidence for nursing practice Press. (7th ed.). Philadelphia: Lippincott Williams \& Wilkins.

Qu, R., Janssen, O., \& Shi, K. (2015). Transformational leadership and follower creativity: The mediating role of follower relational identification and the moderating role of leader creativity expectations. The Leadership Quarterly, 26(2), 286-299.

Rabbi, F., Ahad, N., Kousar, T., \& Ali, T. (2015). Talent management as a source of competitive advantage. Journal of Asian Business Strategy, 5(9), 208-214.

Reiche, B. S., Bird, A., Mendenhall, M. E., \& Osland, J. S. (2017). Contextualizing leadership: a typology of global leadership roles. Journal of International Business Studies, 48(5), 552-572.

Saunders, M., Lewis, P., \& Thornhill, A. (2011). Research methods for business students (5th ed.). New Delhi: Pearson Education Limited.

Schutt, R. K. (2006). Investigating the social world: The process and practice of research (5th ed.). Thousand Oaks: Sage.

Sheehan, M. (2012). Developing managerial talent: Exploring the link between management talent and perceived performance in multinational corporations (MNCs). European Journal of Training and Development, 36(1), 66- 85.

Sparrow, P., Hird, M., \& Cooper, C. L. (2015). Strategic talent management. In Do We Need HR? (pp. 177-212). Palgrave Macmillan, London.

Storey, J. (2016). Changing theories of leadership and leadership development. In Leadership in Organizations (pp. 33-58). Routledge.

Tichy, N. M., \& DeVanna, M. A. (1986). The transformational leader. New York: John Wiley.

Tichy, N. M., \& DeVanna, M. A. (1990.). The transformational leader (2nd. ed.). New York: John Wiley.

Van Vianen, A. E., Shen, C. T., \& Chuang, A. (2011). Person-organization and person-supervisor fits: Employee commitments in a Chinese context. Journal of Organizational Behavior, 32(6), 906-926.

Wat, D., \& Shaffer, M. A. (2003). Equity and relationship quality influences on organizational citizenship behaviors: The mediating role of trust in the leader and empowerment. Personnel Review, 34(4), 406-422.

Weerakkody, D. (2011). Talent's magnet: an awesome place to work. Retrieved from http:// www.island.lk/index.php?page cat=article-details\&page $=$ article-details \& code title $=19026$.

Yukl, G. (1999). An evaluation of conceptual weaknesses in transformational and charismatic leadership theories. Leadership Quarterly, 10(2), 285-305.

Zikmund, W. G. (2010). Business research methods. (8th ed.). Mason: OH: South-Western Cengage Learning. 